\title{
Human Rights For Women Or The Human Rights Of Women?: Pakistan, CEDAW And The Gatekeepers
}

\author{
Anoosh Khan \\ Department of Gender Studies \\ University of Peshawar
}

\begin{abstract}
This paper demonstrates why it is important to have a separate international covenant for the human rights protection of women or CEDAW. The paper begins by discussing the birth of human rights and its evolution to human rights of women in particular. Using Pakistan as an example, the paper discusses Pakistan's CEDAW country reports to date. The key issues presented by the Government of Pakistan in it's state CEDAW reports are highlighted. Then, applying the 'gatekeeper theory' some of the findings of the respective shadow reports are highlighted. Finally, there are suggestions for a plan of action that should be adopted by the Government of Pakistan to ensure human rights in general and the human rights of women in particular.
\end{abstract}

Key Words: Human Rights of Women, CEDAW, Gatekeepers, Pakistan

$$
\begin{aligned}
& \text { تلخيص }
\end{aligned}
$$

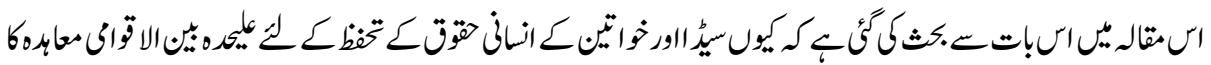

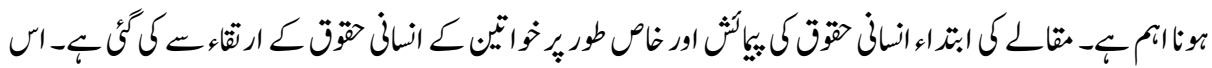

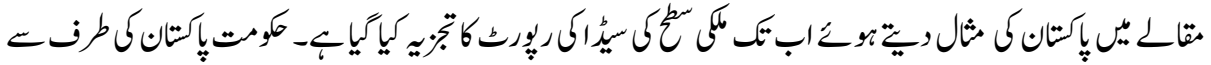

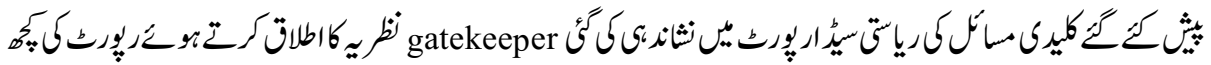

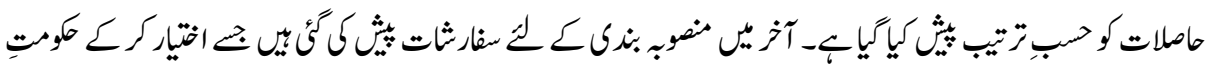

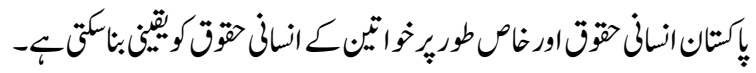

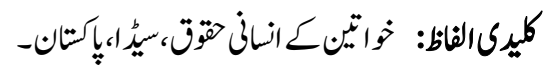

\section{Introduction}

'Human Rights' - the phrase and practice guarantee or at least seem to guarantee a promise, assurance, pledge, declaration, undertaking, and/or an assertion-everything and anything that is constructive and life saving for human beings. However, the pertinent question that one should ask, with all the hype and liberatory movements 
surrounding us is, "are we really living in a world that ensures human rights?" Consequently, our next query should be if we talk about human rights then why do we have to talk about the human rights of women as a separate category? Do women not form a part of the human rights framework and thus are not a part of the human rights campaign? Or are they simply not worth it?

This paper demonstrates why the human rights of women had to evolve as a separate category within the general framework of human rights. In order to trace the development of the human rights of women the paper first looks at the evolution of human rights concepts and framework through the centuries. Then it examines the stance of some modern western philosophers and some important $20^{\text {th }}$ century documents that laid the foundations for current human rights, paving way for the Universal Declaration of Human Rights (UDHR), the human rights covenants and treaty bodies, especially CEDAW. Using Pakistan as an example the country CEDAW reports to date are discussed. Then, applying the 'gatekeeper theory' (Bob, 2009) there is a discussion on some of the findings of three shadow reports. Finally, there are suggestions for a plan of action that should be adopted by the Government of Pakistan to ensure the human rights of women in Pakistan.

\section{A Brief Evolution of Human Rights: Background and Rational ${ }^{2}$}

Some scholars, like Micheline Ishlay (1997, pp. 2-6) suggest that the idea of human rights dates back to the Old Testament (Exodus 22, pp. 20-27 states, "Thou shalt neither vex a stranger, nor oppress him; for you were strangers in the land of Egypt" and Leviticus 19, pp.13-19 states, "neither shall thou stand aside when mischief befalls thy neighbor"). Buddhist ideology also preaches, "I take upon myself the burden of all suffering... all beings I must set free." In a similar vein, a number of Islamic scholars trace human rights as an integral concept of the Islamic philosophy as well. Whereas, Lacquer and Rubin (1989) begin the birth of human rights with the English secular legal document, the Magna Carta (Great Charter) of 1215. The Magna Carta was important because human rights reject absolute power. But the rights that this document stated were specific either to the church or people of specific social standings. However, in the $17^{\text {th }}$ century England the idea that human beings have rights because of being humans, that is, they have Natural rights, was communicated, for example, through the case of the Diggers.

Thomas Hobbes is one of the pioneers among western philosophers who believes that human beings are entitled to universal rights, especially rights to physical survival. For him the ultimate fundamental right for all human beings is the right to life. Thus, Hobbes advocates that other values such as culture and industry come after the right to life is secured. 
Hobbes's successor, John Locke, like Hobbes believes in the rights of individuals qua individuals and that the individual's obligation to the state is reciprocal, that is, it is based on the state's respect and protection of individual's rights. However, unlike Hobbes, Locke expands the realm of rights, adding the rights of liberty and property to the right of life.

While Hobbes ties rights to individual physical security, and Locke believes in both physical rights and property rights, Rousseau adds equality and fraternity to the list of rights. As such Rousseau presents his theory of social contract because he argues that when we use the word "property" we should mean legitimate possession and not just verbal possession, so that the state and its citizens recognize and protect what is legitimately owned by someone else. Rousseau advocates that all male citizens should be property holders to be able to participate in political life and making of the laws.

By the end of the $18^{\text {th }}$ century there were some documents, drafted by political actors, as to what constitutes human rights, especially against monarchial absolutism. These documents include the Magna Carta of 1225 and the English Bill of Rights of 1689. But the "grand documents" of human rights are the French and the American documents drafted at the end of the $18^{\text {th }}$ century. These are the U.S. Declaration of Independence (1776), the U.S. Constitution and its first ten amendments, which constitute the Bill of Rights (1789 and 1791), and the French Declaration of the Rights of Man and Citizen (1789). The Declaration of Independence is the first document to declare that, "All men are created equal; that they are endowed by their creator with certain inalienable rights."

The U.S. Constitution permitted property qualifications for voting but with the exclusion of women and slaves from the political process. Whereas, the Bill of Rights elaborated the set of rights that were not restricted to the citizens of the country. With the exception of slaves, all people were considered by the constitution to have rights such as habeas corpus, trial by jury, freedom of speech, association and religion. Similarly, the French Declaration of Rights of Man and Citizen was not meant only for the French but all people.

However, there was some rejection of universal human rights in the $18^{\text {th }}$ and $19^{\text {th }}$ century. The anti-rationalist approach is manifested in the works of Edmund Burke, who believes in the organic view of politics rather than abstractions such as rights of man. He argues that political institutions could not be deliberately planned; they result from the living customs and traditions in the society. Whereas, David Hume thinks that the feelings of pleasure and pain are root of morality. According to Hume, sympathy, not reason, is the quality that makes humans social beings. Like Hobbes and Hume, Jeremy Bentham also believes that emotions of pleasure and pain provide a much firmer foundation for building theories of politics and law. Finally, Karl Marx with his theory of historical 
materialism rejects the concept of universal rights. Marx's rejection stems because the "rights of man" equate to the "rights of bourgeois man." Thus, Marx believes that as long as there are social classes rights can never be universal.

However, the middle of $19^{\text {th }}$ century up to the mid $20^{\text {th }}$ century witnessed a lot of domination and deliberately inflicted human suffering. The combination of the world war, totalitarianism and genocide was the ultimate blow to any concept of human rights. Therefore, something official had to be done when World War II was over and Nazism defeated. First some Nazi leaders were tried for crimes against humanity. Second the United Nations (UN) was created for global understanding and cooperation. Third the United Nations issued official statements on human rights which were intended to represent a consensus of international opinion. Besides, the atrocities committed against humanity in the $20^{\text {th }}$ century made it pertinent to have human rights spelled out in the form of written documents. As a result, the first specific declaration on human rights, the United Nations Universal Declaration of Human Rights (UDHR) was presented in 1948. The UDHR refers to the political, economic, social, and cultural rights. The crucial concept that it advocates is that of human dignity. Two other documents that followed are 1966 documents which include the International Covenant on Civil and Political Rights (ICCPR) and the International Covenant on Economic, Social and Cultural Rights (ICESCR). These three documents together are referred to as the "International Bill of Rights." Besides these covenants, there are also documents that prohibit violations of single right. These specifically deal with racial discrimination, discrimination against women, against torture, rights of child, rights of migrant workers, disability rights, and enforced disappearance. ${ }^{3}$

\section{Women and Human Rights}

As the discussion above suggests, with the passage of time and the efforts of human rights advocates, many changes for the better were incorporated in the human rights philosophy and the written documents. However, a question that arises is that why do women become a separate topic for human rights? As stated earlier, are women not humans and thus not a part of the human rights evolutionary thought process?

The answer to this, maybe, lies partly in the critical textual analysis of human rights documents and partly in the societal mores of the time-then and now. Perhaps a close textual analysis of the UDHR, ICCPR, and ICESCR to some extent can provide an answer. Whether one looks at the religious texts, the philosophical texts of $18^{\text {th }}$ and $19^{\text {th }}$ centuries or even the human rights documents of $20^{\text {th }}$ century, humanity is addressed by the collective 'Man' and the pronoun(s) therefore used are 'he,' 'him' or 'himself.' So much so, the written text of UDHR is also gender bias. Interestingly, most of the UDHR articles begin either with 'All human beings,' 'Everyone,' 'No one,' and 'All.' But the 
qualifying pronoun(s) for the antecedents is either 'he/his.' The only article in UDHR that specifically mentions men and women separately is article 16 (1), which states, "Men and women of full age, without any limitation due to race, nationality or religion, have the right to marry and found a family."

Similarly most of the articles of the ICCPR begin with 'All people,' 'Every human being,' 'No one,' 'Everyone,' 'All persons,' and yet the qualifying pronoun(s) used is 'he/him.' The only ICCPR article that mentions men and women explicitly is the one that also deals with marriage rights. ICCPR Article 23(2) states, "The right of men and women of marriageable age to marry and to found a family shall be recognized."

However, the text of ICESCR is comparatively less gender biased than the two afore mentioned texts but at times some of the articles here also use pronouns like he/him/himself to qualify 'All people,' 'Everyone,' and 'All.' The ICESCR includes two articles that distinctively use men and women as separate entities. ICESCR Article 3 states:

The State Parties to the present Covenant undertake to ensure the equal right of men and women to the enjoyment of all economic, social and cultural rights set forth in the present covenant.

And Article 7a (i) states:

Fair wages and equal remuneration for work of equal value without distinction of any kind, in particular women being guaranteed conditions of work not inferior to those enjoyed by men, with equal pay for equal work.

As such, UDHR and ICCPR only mention women with reference to marriage rights. The reason being that the document writers conceived of heterosexual marriage only; for them the only way to have a 'natural' family was through the conjugal union between a 'natural' man and a woman. Therefore, men and women had to be actually spelled out. However, I think that the text of ICESCR is slightly less gender biased because the propagation of culture and the social mores, in most cultures, is believed to be perpetuated through women, especially through mothers.

On the whole, the International Bill of Rights (UDHR, ICCPR, and ICESCR), as far as the written text is concerned, apparently seem gender bias or at best gender blind. Although these documents, in spirit, may not have meant to sound as biased as they appear to be. In other words, the lack of gender neutrality of these documents suggests the patriarchal social mores and thus the language usage that may have been part of the discursive practices of those days, preserving and promoting a certain social value system. But the dilemma with all such texts, as with religious texts, is that the interpretation 
becomes problematic, especially when patriarchy, power, hierarchy, and culture intervene. Therefore, further documents and texts are required to clarify the misinterpretation of language and intention especially in times, cultures, and issues where the male-female dichotomy makes a difference and can lead to serious consequences if rules and rights are not clearly explained.

\section{CEDAW: Birth, Benefits and Limitations}

Convinced that the full and complete development of a country, the welfare of the world and the cause of peace require the maximum participation of women on equal terms with men in all fields. ${ }^{4}$

Although the United Nations human rights documents guarantee equality and nondiscrimination on the basis of sex, however, these documents overall do not have specific rights for women. As such, when the word 'women' did not actually appear much in these human rights documents it called for a heads up! Women have always been marginalized in societies since time immemorial and when women did manage to get their rights either through religious or secular mechanisms the patriarchal structures and interpretations impeded women from achieving the status or issues they were struggling for and against. Therefore, a separate and clearly spelled out set of rights for women had to be developed. This separate set of rights was not only meant for women but also for men who could use it for further interpretation of the existing human rights. Since the missing-out-of-women was strongly felt in the human rights documents, as a result, The Convention on the Elimination of All Forms of Discrimination Against Women (CEDAW) was adopted in 1979 by the UN General Assembly and entered into force on September 2, 1981. CEDAW Article 1 defines discrimination against women as, “...any distinction, exclusion or restriction made on the basis of sex."

CEDAW broadly covers all aspects of women's lives including political participation, health, education, employment, marriage, family relations and equality before the law. CEDAW has definitely helped in interpreting women issues within the UN human rights framework. However, this treaty body has limitations as well. Firstly, like other UN human rights documents, the problem of universalism vs. particularism plays an important role in implementing CEDAW across the board. Most of CEDAW articles can be applied universally but then some State Parties have reservations regarding some articles on the basis of their cultural and social traditions. This further leads to the problem of what constitutes violations of human rights from a particular culture's standpoint and consequently what violations can therefore be over looked on the basis of cultural particularism and how far? Secondly, a strict check, on the State Parties, with regard to implementation of CEDAW is not possible. Therefore, CEDAW country reports, if submitted in time or at all, to the CEDAW Committee cannot be entirely 
trusted for their reporting procedures and results. Finally, with the help of CEDAW or other human rights documents the naming and blaming of a State Party, for not properly implementing a treaty, is possible but the shaming is not guaranteed as CEDAW and other covenants are not legally binding and therefore no State Party can be legally penalized in any way.

However, during the course of time other conventions and conferences have also taken place to ensure and reiterate the importance of CEDAW and women's rights in general due to which parallel systems, like national and international non-governmental organizations, are formed. These organizations help to monitor the proper implementation, reporting and documentation of a treaty by State Parties. As State Parties frame their CEDAW reports these institutions and mechanisms work simultaneously to produce parallel or shadow reports to highlight the similarities and differences reported by the State Parties to the CEDAW Committee. These non-governmental organizations thus provide a structure to maintain some sort of checks and balances-at least they manage to highlight the performance of the State Parties and if required bring about some sort of a response both at the national and international platforms. These reactions may not always accomplish the goal, for which there is an on-going struggle, though some times they do, but these voices and responses definitely draw attention, enabling women to become visible and heard.

As a case in point Pakistan's CEDAW country reports and shadow reports of NGOs elucidate the functioning of the Covenant in Pakistan. Pakistan had submitted three joint country reports in 2007 which covered the period from 1997 to December 2004. However, the latest report was due in April 2009 but was presented in September 2011, covering a period from January 2005 to April 2009.

\section{A Brief Overview of CEDAW and Pakistan}

Pakistan ratified CEDAW on April 12, 1996. It presented its reports to the CEDAW Committee at the thirty-eighth session, held at United Nations Headquarters in New York from May 14 to June 1, 2007. Pakistan, until now has submitted four country reports. The initial report was supposed to be submitted on June 11, 1997, the second report was due on June 11, 2001 and the third report was due on June 11, 2005 and the fourth report was due in April 2009. However, the initial three reports were jointly submitted to the CEDAW Committee on July 28, 2005. A compliance report was due within a year's time but somehow it could not be produced along with subsequent two periodic reports that were supposed to be submitted by the Ministry of Women Development. The fourth CEDAW Country Report is also produced by the Ministry of Women Development in consultation with the key government and civil society organizations. ${ }^{5}$ 


\section{Pakistan CEDAW Combined Country Report Summary}

Pakistan acceded to the Convention on the Elimination of All Forms of Discrimination against Women (CEDAW), making a declaration on the Convention and entering a reservation on Article 29 (1):

a) Declaration: "The accession by [the] Government of the Islamic Republic of Pakistan to the [said Convention] is subject to the provisions of the Constitution of the Islamic Republic of Pakistan."

b) Reservation: "The Government of the Islamic Republic of Pakistan declares that it does not consider itself bound by paragraph 1 of article 29 of the Convention."

The country's combined periodic report(s) was presented by the then Secretary of Ministry of Women and Development, Government of Pakistan. This section primarily summarizes the main points of all the reports as submitted before the CEDAW Committee. In order to empower women in Pakistan, according to the combined report, the following measures were adopted at the policy, administrative and institutional levels: ${ }^{7}$

- In 1998, a National Plan of Action (NPA) was launched.

- The First National Policy for Development and Empowerment of Women was prepared

- Education Sector Reforms Action Plan (ESR) and the National Plan of Action for All was developed.

- For the Economic Empowerment of Women Pakistan launched its 'Poverty Reduction Strategy Paper' (PRSP) and it ratified Convention 100 of ILO on "Non Discrimination of wages on the basis of sex."

- Political Empowerment of Women was ensured through Ordinance 2001 which accounts for 33\% representation of women at all tiers of elected bodies; Women Political Schools are established; and the role of media in advocacy of women rights is encouraged.

- The Judiciary is constantly struggling to protect women's rights. The government ensured to sensitize the judiciary on women's issues; women are being encouraged to join the legal and judicial profession; and the curriculum of Federal and Provincial Judicial Academies now include a module on gender sensitization.

This, in short, was a very brief summary of Pakistan's combined CEDAW country report(s). ${ }^{8}$

\section{Fourth CEDAW Country Report}

In a nutshell, the fourth CEDAW country report covers almost the same aspects as were dealt with in the previous reports. The report begins by stating that the recent years were 
challenging times for Pakistan. However, very briefly, the report covers the following areas:

- Natural Disasters which include the earthquake of October 2005; heavy rains in July 2007; and the torrential rains of August 2008 which caused massive floods in NWFP and Punjab Provinces.

- Economic Challenges.

- Humanitarian Challenges like helping IDPs from FATA who are evacuated from their homes due to terrorist activities.

- Introduction of new laws for women empowerment like Protection against Harassment of Women at the Workplace Act (2009); and the Domestic Violence Prevention and Protection Act 2009.

- The government is also working on systematizing gender-disaggregated data. The government has established mechanisms for: informal dispute resolution; measures to address internal and external women trafficking; developed women economic and political empowerment schemes; tackling health issues; launched poverty eradication programs; made significant strides in the education sector; and worked on the promotion of women employment. ${ }^{9}$

This in brief was the summary of various CEDAW reports provided by the Government of Pakistan to the CEDAW committee. The next section examines some of the respective shadow reports provided by various NGOs to the CEDAW committee.

\section{Pakistan CEDAW Shadow Reports}

In order to highlight some of the omitted issues in the reports the role of the gatekeepers, especially the international/national NGOs, becomes important. These shadow reports draw attention to the ground realities and the implementation/or not of CEDAW as actually practiced in the country under discussion/observation. The shadow reports sometimes also highlight areas/issues that consciously or unconsciously are left out of the submitted reports. Hence, in the following section looks at the summaries of three shadow reports; issues and questions raised by the CEDAW Committee; Pakistan's response to the Committee; and a brief summary of the concluding comments of CEDAW Committee about Pakistan's combined periodic reports. Finally, it highlights the findings of the fourth shadow report.

For the initial three combined reports two parallel or shadow reports were submitted by Shirkat Gah-Women's Resource Center and National Commission for Justice and Peace with Democratic Commission for Human Development (with endorsement and inputs from other major national NGOs and institutions). 
Shirkat Gah-Women's Resource Center-Talibanization and Poor Governance: Undermining CEDAW in Pakistan (April 15, 2007) ${ }^{10}$

One of the foremost appeals made by this shadow report to the CEDAW Committee is to ask the Government of Pakistan to explain the measures adopted against the mounting threat of "Talibanization" in the country; reasons for ineffective governance; and lack of ownership on part of the government bodies. In a similar vein the report highlights the detrimental consequences of militant campaigns which denounced contraceptives and polio vaccines; deemed girls' education un-Islamic; attacked girls' schools, health workers and NGOs; enforced women to wear veils; destroyed barber, video and music shops.

Other problems included in this shadow report are ineffective data, incomplete records, and no implementation of existing provisions. So much so that this shadow report deems the National Plan of action (NPA) and other policies for women, "defective, hasty legal measures."

Consequently, Shirgat Gah's report requests the CEDAW Committee to inquire from the Government of Pakistan about the following areas, issues and processes: ${ }^{11}$

- Ineffective implementation of CEDAW

- Government strategies to curb Talibanization;

- Legal status and autonomy of National Commission on the Status of Women (NCSW);

- Issues of effective governance with regard to birth, death, marriage records; gender segregated data; registered women voters and women's political participation;

- VAW/medico-legal facilities/police sensitization training;

- The material and physical conditions of crises/women centers and shelters;

- Legal protection of women workers;

- Personal status of minorities; and

- Political representation of women in local government bodies.

National Commission for Justice and Peace (NCJP) with Democratic Commission for Human Development (DCHD)_Discrimination Lingers On...: A Report on the Compliance of CEDAW in Pakistan (February 15, 2009).

The shadow report submitted by NCJP and DCHD echo similar issues as brought to light by Shirkat Gah's report. This report highlights that CEDAW has not been translated into domestic laws; the Constitution of Pakistan does not define discrimination against women; there is no specific law for domestic violence; some family and minority laws 
are discriminatory towards women; and most national plans for the betterment of women lack implementation. ${ }^{12}$

Comparing both the shadow reports the issues highlighted resonate almost similar claims, as opposed to what the government claims in its CEDAW country report(s). For example, CEDAW provisions are not translated into domestic laws; discriminatory practices within the legal framework, by legal institutions and executioners continue; cultural (mal)practices continue; women are given representative positions in the government but overall not allowed to practice their rights of political participation; biased practices regarding women's education, health and work also persist; human rights violations of the minority women also continue.

\section{CEDAW Committee's Questions and Pakistan's Response ${ }^{13}$ on the Combined Initial, Second, and Third Reports}

The CEDAW Committee, after examining Pakistan's report raised a few concerns. The questions put forward basically emphasized the following themes; Firstly, the CEDAW Committee required that the State Party (Pakistan) should provide substantive evidence of the various claims of achievement regarding the implementation of CEDAW provisions and the objectives achieved in accordance. Secondly, in order to substantiate the facts provided, the State Party should include more statistical figures and data for comprehensive analysis and credibility. Thirdly, in compliance with CEDAW the State Party has initiated a number of national schemes but in order to prove its seriousness it is pertinent that an exact timeline is provided for accomplishing the said or expected goals. Fourthly, the mechanisms provided and implemented to achieve objectives should also be explained more concisely. Last, but not the least, the State Party has to provide a comprehensive scheme or plan of action for monitoring and evaluation of CEDAW provisions in all walks of life and institutions.

In response to the above issues, raised by the CEDAW Committee, Pakistan provided a detailed reply incorporating statistics, graphs and charts, and in depth answers to questions asked in particular. ${ }^{14}$ Perhaps the somewhat satisfying response of Pakistan to the CEDAW Committee led the Committee to praise the efforts taken by the State Party to comply with the CEDAW provisions (articles 1-10 of the concluding remarks). Without going into details, it is worth noting that the concluding remarks, with a few exceptions, almost reiterate the concerns accentuated by the above shadow reports. While reading the concluding remarks it feels as if the Committee relies more on the shadow reports than the State Party reports! ${ }^{15}$ Nevertheless, the CEDAW Committee in the concluding comments urges Pakistan to ratify the Optional Protocol to CEDAW and that Pakistan should consider ratifying all the other treaties to which it is not a party. The Committee also requests that the concluding remarks should be widely disseminated 
among officials, political representatives, human rights organizations, and the general public. And that Pakistan should submit its next Country report due in April 2009.

The above discussion explicates the role of the gatekeepers in implementing a treaty body and in helping the CEDAW Committee to look beyond the country reports provided by the State Parties. The reason for providing a summary of the two shadow reports is to compare and contrast the accuracy of the CEDAW country reports and the gross ground realities as elucidated by the shadow reports. Since CEDAW provisions are not legally binding therefore, discrimination against women continues. However, with the rise of general awareness, especially through the media, some of the people and institutions are beginning to raise concerns about the implementation of CEDAW provisions. For example, a Pakistani English newspaper reported on what was happening regarding CEDAW report. ${ }^{16}$

The CEDAW provisions in Pakistan, no doubt, are difficult to implement first because the treaty is not legally binding nor translated into domestic legal frameworks and second due to the rigid cultural practices, topped by the Taliban influences. However, besides these factors there are other factors at play as well. The first and foremost reason is the high illiteracy level of the citizens. This includes both the male and female high illiteracy levels. Illiterate women definitely and some literate women also are dependent on their male counterparts but illiterate men pose a bigger challenge: they do not understand the importance of education in general and female education in particular. Secondly, the political processes of the government of Pakistan; the institutions, and bureaucracy are unstable. As a result, the status of non-legal treaties like CEDAW becomes vulnerable in terms of procedural concerns like implemention, evaluation and reporting. The reason being, every new government wants to do it their way, with their people, some times undoing even the good steps taken by previous governments. Thirdly, CEDAW provisions enforced the government of Pakistan and the like to reserve 33\% quota for female participation in the political affairs of the country but the women elected to the office do not have any authority per se; they cannot do anything without prior permission from their male counterparts, who happen to be in a majority as well. Perhaps this 'silence' observed by the female political representatives is aptly questioned by a Pakistani columnist in 2009. ${ }^{17}$

\section{Pakistan NGO Alternative Report on CEDAW 2012: Critique by Aurat Foundation}

This section elucidates the executive summary points of the shadow report prepared by Aurat Foundation in connection with the Fourth CEDAW State Party Report presented by Government of Pakistan to the CEDAW Committee. The report highlights the following points:

- The State's reluctance to ratify the Optional Protocol to CEDAW. 
- The Constitution of Pakistan neither defines discrimination against women as defined in CEDAW articles1, 7, and 15 nor does any legislation mirrors such a definition either.

- The Ministry of Women Development (MoWD) and the National Commission on the Status of Women (NCSW), lack sufficient human, financial resources, and/or technical capacity to perform effectively; they only play an advisory role.

- Two of the Hudood Ordinances, responsible for sending hundreds of women to prison on charges of sexual relationships outside marriage, have been amended by the Protection of Women (Criminal Laws Amendment) Act 2006. But two Ordinances (the Offences against Property and Prohibition Ordinances), which are equally controversial, defective, discriminatory and contentious, have remained untouched.

- The Domestic Violence (Prevention and Protection) Bill 2009 passed by the National Assembly was also impeded by the Council of Islamic Ideology.

- Trafficking of women continues within and outside Pakistan. The different categories like trafficking, smuggled persons or trafficked persons in the guise of marriage, etc. are not differentiated.

- The judiciary still lacks women in senior positions.

- Female political participation, for running or voting for office, is still uncertain compared to their male counterparts.

- As per the Citizenship Act 1951, Pakistani women still cannot sponsor foreign husbands.

- The quality of life in Pakistan is generally deteriorating mainly because of lack of education; increasing poverty; militancy; displacement of war affectees; and the cultural mindset about the status of women.

- With the exception of the West Pakistan Maternity Benefits Ordinance, 1958, the West Pakistan Maternity Rules, 1961, and Protection against Harassment at Workplace Act 2010, there are no special laws to protect rights of women at the work place, despite specific provisions for special law making under Article 25(3).

- Widows, single women, women with disabilities and the transgendered community are a largely ignored group without any rights and status.

- Despite the claims of Government health is not a priority.

- Personal laws in Pakistan are both inadequate and flawed: non-Muslim women are discriminated on the basis of sex and religion.

However, on the positive side, newspaper articles, other media presentations and discussion forums create public spaces to debate and generate awareness about women oppression, discrimination and their subsequent rights. Therefore, those who are in a better position academically, legally, socially and economically feel obligated to 
pressurize the government to take necessary measures to enforce CEDAW and other such provisions present. $^{18}$

\section{Conclusion: A Suggested Plan of Action}

Julie Mertus (2009, p.1) states, “...among human rights advocates, the dominant wisdom is that the promotion and protection of human rights rely... more on domestic action." Therefore, in order to ensure human rights implementation National Human Rights Institutions (NHRIs) are set up in some of the States that are signatories to the UDHR. Elaborating on the characteristics of NHRIs Mertus (2009, p. 3) states:

A distinct aspect of NHRIs is the space in which they maneuver; an imagined space between the state and civil society.... Given that NHRIs are government-financed and government-initiated endeavors, created by legislative decree or through the national constitution, it is extraordinary that they maintain their independent stance... [if] they are ever able to do so.

Accordingly, apart from local and international NGOs in Pakistan, there also exists the Human Rights Commission of Pakistan (HRCP). The HRCP was established in 1986 and since then has been trying to work on a broad range of human rights issues. However, there are many issues that the HRCP on its website claims to have either dealt with or is currently addressing. Unfortunately, they themselves claim that due to various reasons much has not been achieved. ${ }^{19}$ The question arises that in the presence of HRCP, national and international NGOs, the Ministry for Women Development and above all Pakistan being a signatory to CEDAW and other human rights conventions why human rights are being violated? More so, why the rights of women are being violated the most? Perhaps there is not an easy or a single answer to this question. There are so many intersectional reasons like religion, race, class, governance, economics, literacy, and cultural mores that the ideal implementation of human rights mechanisms and achievement becomes a multilayered complicated process. However, some of the following strategies may help in overcoming few of the existing hurdles that hinder the achievement of human rights in general and the human rights of women in particular.

First, since Pakistan is a signatory to CEDAW, in order to fully incorporate itself as a State Party Pakistan should ratify the CEDAW Optional Protocol because,

...the Optional Protocol's most immediate effect will be to strengthen the [women's] Convention's existing enforcement mechanism....the Protocol gives women a specific set of procedural rights, allowing them direct access to the protections of the [women's] Convention (Hoq, 2001, p. 678). 
Second, complying with the CEDAW expectations Pakistan, with the help from the Ministry for Women Development (MoWD), has set up a National Commission on the Status of Women (NCSW) and the respective Provincial Commission on the Status of Women (PCSW). As Pakistan boasts of a 33\% seat allocation for women in the federal, provincial and local political bodies therefore in order to achieve pragmatic results the government of Pakistan should begin by allowing both the MoWD and NCSW self autonomy by allocating workable budgets, human resource and independent decision/policy making processes. Besides, when it comes to selecting members for the executive committee for NCSW and PCSW (in particular) those people should be selected who have relevant knowledge and experience as opposed to those who have political affiliation with the ruling government, especially in the province.

Third, while these institutions work on women related issues and policies they should involve the civil society by incorporating NGOs, women institutions, academia, and the direct beneficiaries from the grassroots level. Whereas, the HRCP can be given a choice if it would also like to work in collaboration with them or independently towards achieving the same goals.

Fourth, the role of academia should be stressed. In Pakistan, the combination of civil society, NGOs and academia working for social justice is still not really in vogue yet. ${ }^{20}$ Why this combination is important because it will not only operationalize human rights concepts at practical levels but it will also generate future, "trained" human rights advocates and activists. There can be trained human rights advocates and activists in Pakistan if gender sensitization and human rights approaches are incorporated in the curricula and syllabi at all academic levels. Besides, the government should encourage and establish academics links and scholarship programs with foreign universities who have the expertise and Human Rights departments. By ensuring proper human rights training the government and civil bodies will have a bank of human resource to draw from for various human rights and especially women rights sensitization training, advocacy and activism programs, rather than employing people who learn human rights concepts by trial and error.

Fifth, all institutions working in and for human rights should ensure working on mechanisms by which human rights treaties are taken seriously by the government, attain some sort of a legal status culturally and/or have at least serious evaluative mechanisms.

Finally, while fighting the war on terror and trying to be accountable to superior world powers, the government of Pakistan, the gatekeepers, and human rights advocates should develop transparent self evaluation programs and mechanisms that show a true picture of CEDAW implementation, recording, and reporting even if there are no 'masters' or 'superiors' to interrogate them. 


\section{End Notes}

1. I have deliberately used the two prepositions, 'for' and 'of', in the title to make a statement. 'For' is a preposition that usually suggests that someone else is doing or giving something to someone e.g. as a gift, charity, a gesture of kindness, or even reluctantly etc. Whereas, 'of' is a possessive preposition, suggesting the rightful possession or belonging of someone to or toward something - that is the rightful ownership.

2. For tracing the historical development of Human Rights I borrow from A. Belden Fields. (2003). Rethinking Human Rights for the New Millennium. New York: Palgrave Macmillan.

3. For details see Mertus. (2005). Chapter 4: UN Treaty Bodies. In The United Nations and Human Rights: A Guide for New Era. $2^{\text {nd }}$ edition, (pp. 82-97). New York: Routledge.

4. CEDAW Text: Introduction. http://www.un.org/womenwatch/daw/cedaw/text/ econvention.htm\#intro. Electronic document, accessed October 1, 2009.

5. Taken from fourth report. http://www.bayefsky.com/docs.php/area/reports/treaty/ Cedaw/state/130/node/4/filename/pakistan_cedaw_c_pak_4_2011, accessed October $18,2013$.

6. Taken from the original report. CEDAW/C/PAK/1-http://daccessdds.un.org/doc/ UNDOC/GEN/N05/454/37/PDF/N0545437, p. 8. Electronic document, accessed September 25, 2009.

7. For details see Introductory Statement. http://www.un.org/womenwatch/daw/cedaw/ cedaw38/statements/delegations/Pakistan_intro_statement.pdf. Electronic document, accessed September 25, 2009.

8. For details see Responses to the Expert Committee's concluding comments (CEDAW/C/PAK/CO/3) on the combined initial, second and third periodic report. http://www.bayefsky.com/docs.php/area/reports/treaty/Cedaw/state/130/node/4/filena me/pakistan_cedaw_c_pak_4_2011, accessed October 18, 2013.

9. For details see "Fourth Periodic Reports of States Parties, Pakistan." http://www.bayefsky.com/docs.php/area/reports/treaty/Cedaw/state/130/node/4/filena me/pakistan_cedaw_c_pak_4_2011, accessed October 18, 2013.

10. Shirkat Gah-Women's Resource Center. (April 15, 2007).Talibanization and Poor Governance: Undermining CEDAW in Pakistan. http://www.shirkatgah.org/CEDAW\% 20report\%20(PDF\%20format).pdf. Electronic document, accessed September 27, 2009.

11. I am selecting few major issue headings from the executive summary of the shadow report submitted by Shirkat Gah in April 2007.

12. For details see National Commission for Justice and Peace with Democratic Commission for Human Development. (February 15, 2009). Executive summary. Discrimination Lingers On...: A Report on the Compliance of CEDAW in Pakistan. 
http://www.iwraw-ap.org/resources/pdf/Pakistan\%20SR\%20(NCJP).pdf. Electronic document, accessed September 27, 2009.

13. Here I infer the suggestive themes. For details see "List of issues and questions with regard to the consideration of an initial and periodic report." Committee on the Elimination of Discrimination against Women. Pre-session working group for the thirty-eighth session 14 May-1 June 2007. http://daccessdds.un.org/doc/UNDOC/ GEN/N06/555/23/PDF/N0655523.pdf?OpenElement. Electronic Document, accessed September 28, 2009.

14. For details see "Responses to the list of issues and questions for consideration of the combined initial, second and third periodic report of Pakistan." Committee on the Elimination of Discrimination against Women. Pre-session working group for the thirty-eighth session 14 May-1 June 2007. http://daccessdds.un.org/doc/UNDOC/ GEN/N07/254/01/PDF/N0725401.pdf?OpenElement. Electronic Document, accessed September 28, 2009.

15. For details see "Concluding comments of the Committee on the Elimination of Discrimination against Women: Pakistan." Committee on the Elimination of Discrimination against Women. Pre-session working group for the thirty-eighth session 14 May-1 June 2007. http://daccessdds.un.org/doc/UNDOC/GEN/N07/376/ 08/PDF/N0737608.pdf?OpenElement. Electronic Document, accessed September 28, 2009. It is worth while to compare and contrast the concluding remarks with the shadow report submitted by National Commission for Justice and Peace and Democratic Commission for Human Development.

16. For details see, Myra Imran. Women's ministry to submit report on CEDAW to UN in Oct. The News. September 12, 2009. http://www.thenews.com.pk/daily detail.asp?id=197994. Electronic document, accessed September 26, 2009.

17. For details see, Ardeshir Cowasjee. Zero plus zero equals zero. Dawn: The Internet Edition (Nov. 9, 2008). http://www.dawn.com/weekly/cowas/20080911.htm. Electronic document, accessed September 28, 2009.

18. For a recent critique see: "Women's rights in Pakistan: NGOs compile report to show the 'real' picture." The Express Tribune. December 19, 2012. Electronic document. http://tribune.com.pk/story/481390/womens-rights-in-pakistan-ngos-compile-reportto-show-the-real-picture, accessed April 6, 2013.

19. For details see Human Rights Commission of Pakistan. http://www.hrcp-web.org/. Click Reports: Trend Analysis and see Human Rights Violations- 2005 \& 2006 (Report By Aleyha Ahmed, HRCP Intern 2007) and other reports. This report states, "Overall there has been a substantial increase in human rights violations from 2005 to 2006...." Electronic document, accessed Oct. 19, 2009.

20. Although personally I have been involved in only one such triadic partnership of the government, NGOs and the Department of Gender Studies, University of Peshawar, project called "Gender Justice through Musalihat Anjuman Project." For details see http://www.gjtmap.gov.pk/. 


\section{References}

Aurat Foundation. (2012). Pakistan NGO Alternative Report on CEDAW 2012, Aurat Publication and Information Service Foundation, Islamabad: Crystal Printers. Here accessed from http://www2.ohchr.org/english/bodies/cedaw/docs/ngos/ AuratFoundationPakistanForTheSession_CEDAW54.pdf, accessed March 01, 2014.

Belden, F. A. (2003). Rethinking Human Rights for the New Millennium, New York: Palgrave Macmillan.

Bob, C. (2009). Introduction: Fighting for New Rights, In Clifford Bob (Ed.). The Struggle for New Human Rights, (pp. 1-13). Philadelphia: University of Pennsylvania Press.

Cowasjee, A. (2008). Zero plus zero equals zero. Dawn: The Internet Edition, Nov. 9. http://www.dawn.com/weekly/cowas/20080911.htm, Electronic document, accessed September 28, 2009

Hoq, L. A. (2000-2001). The Women's Convention and Its Optional Protocol: Empowering Women to Claim Their Internationally Protected Rights, Columbia Human Rights Law Review, vol. 32, pp. 677-726.

Imran, M. (2009). Women's ministry to submit report on CEDAW to UN in Oct, The News, September 12, http://www.thenews.com.pk/daily_detail.asp?id=197994, Electronic document, accessed September 26, 2009.

Ishlay, M. R. (Ed). (2007). The Human Rights Reader, New York: Routledge.

Lacqueur, W. and Rubins, B. (Eds.). (1989). The Human Rights Reader, New York: Meridian.

Mertus, J. A. (2009). Operationalizing Human Rights at the Local Level, In Human Rights Matters: Local Political and National Human Rights Institutions, (pp. 113), Stanford: Stanford University Press.

(2005). Chapter 4: UN Treaty Bodies. In The United Nations and Human Rights: A Guide for New Era. (2 ${ }^{\text {nd }}$ ed.). New York: Routledge.

National Commission for Justice and Peace with Democratic Commission for Human Development. (2007). Discrimination Lingers On...: A Report on the Compliance 
of CEDAW in Pakistan. http://www.iwrawap.org/resources/pdf/Pakistan\%20SR

\%20(NCJP). pdf. Electronic document, accessed September 27, 2009.

Pakistan CEDAW Country Reports, 1997, 2001, 2005 CEDAW/C/PSK/1- Electronic document, $\quad$ http://daccessdds.un.org/doc/UNDOC/GEN/N05/454/37/PDF/ N0545437.pdf?OpenElement, accessed September 25, 2009.

Pakistan CEDAW Country Report: Fourth periodic reports of States parties Pakistan. Electronic document. http://www.bayefsky.com/docs.php/area/reports/treaty/ Cedaw/state/130/node/4/filename/pakistan_cedaw_c_pak_4_2011, October 18, 2013.

Shirkat Gah-Women's Resource Center. (2007). Talibanization and Poor Governance: Undermining CEDAW in Pakistan, http://www.shirkatgah.org/CEDAW\% 20report\%20(PDF\%20format). pdf. Electronic document, accessed September 27, 2009.

The Express Tribune. (2012). Women's rights in Pakistan: NGOs compile report to show the 'real' picture, December 19, 2012. Electronic document, http://tribune.com.pk/story/481390/womens-rights-in-pakistan-ngos-compilereport-to-show-the-real-picture, accessed April 6, 2013.

United Nations (1981)Convention on the Elimination of All Forms of Discrimination against Women, Electronic document, http://www.un.org/womenwatch/daw/ cedaw/text/econvention.htm, accessed September 10, 2009.

Dr. Anoosh Khan is Associate Professor and Director in the Department of Gender Studies, University of Peshawar Khyber Pakhtunkhwa, Pakistan. 